\title{
Institutional Capacity and Macroeconomic Performance: Empirical Evidence from Nigeria
}

\author{
Martins Iyoboyi $^{1^{*}} \&$ Latifah, M. Pedro ${ }^{2}$ \\ ${ }^{1}$ Department of Economics \& Development Studies, Federal University Dutsin-ma, Katsina \\ State, Nigeria \\ ${ }^{2}$ Department of Economics, Bayero University, Kano, Nigeria \\ *Corresponding author: Department of Economics \& Development Studies, Federal \\ University Dutsin-ma, Katsina State, Nigeria. E-mail: miyoboyi@fudutsinma.edu.ng, \\ martinsiyo2000@yahoo.com
}

Received: September 20, 2013 Accepted: January 10, 2014 Published: January 20, 2014.

doi:10.5296/rae.v6i1.4309 URL: http://dx.doi.org/10.5296/rae.v6i1.4309

\begin{abstract}
The paper aimed at empirically investigating the impact of institutional capacity on macroeconomic performance of the Nigerian economy for the period 1961-2011. The analysis is based on a multivariate vector error correction model. The empirical results confirm co-integration relationship between institutional capacity, fiscal-monetary policy mix and macroeconomic performance. Results of the generalized impulse response functions suggest that one standard deviation innovation on institutional capacity reduces macroeconomic performance in the short, medium and long term, while results of the variance decomposition indicate that a significant variation in Nigeria's macroeconomic performance is not attributable to changes in the capacity of institutions, based on the proxy employed. It is recommended that for macroeconomic performance to be improved and sustained, mechanisms which deliberately seek to enhance institutional capacity, with a view to stimulating growth and providing the impetus for the achievement of macroeconomic objectives in the short, medium and long term horizons be instituted and vigorously pursued.
\end{abstract}

Keywords: cointegration; generalized impulse response; institutional capacity; variance decomposition; vector error correction model

JEL: E44, E61, E63 


\section{Introduction}

Increasing attention is being paid in recent times to the role of institutions on the performance of an economy. The resurgence of interest is so intense that not only are researchers interested in growth-inducing factors outside the traditional endogenous variables, but interest has spilled over into such areas as the sources of institutional differences observed across countries and regions, in addition to the channels through which institutions may affect the performance of an economy. Whereas the earlier growth literature focused principally on the main proximate causes of growth, recent analyses have shifted emphasis to the study of possible reverse causality flowing from development to institutions, and the relative role that they can play on macroeconomic performance in comparison with other factors such as economic policies, trade openness and the influence of geography.

The question of whether institutional quality contributes to growth and development has been extensively examined. A major conclusion is that institutional quality as an important precondition for growth (Kornai, 2000; Bekaert et al., 2004). The more qualitative are institutions, the greater the tendency for increase in efficiency and equity and thereby growth and development. Institutional capacity therefore provides the template upon which the achievement of macroeconomic objectives across regions and countries can be measured and compared. It is known, for example that policies and programmes in poor regions are not usually implemented due largely to institutional weaknesses and not by the lack of know-how. High-quality institutions are impartial in implementing laws and policies, thus helping to foster the rules and procedures necessary for growth and development (Rothstein \& Teorell, 2008). Chousa et al. (2005) consider institutions and the role played by them, including institutional reforms and rule of law as capable of creating innovative systems for economic growth and development. Consequently, understanding how institutions shape outcomes is useful for policymaking, in that institutions represent the equipment employed by fallible economic agents to change incentives that leverage the process of solving social problems (Ostrom, 2005).

Institutional capacity is generally recognized as imperative to macroeconomic performance, although the extent to which each indicator can help promote the growth process is a subject of intense debate. The conceptual expectations are that adequate institutional capacity should engender efficiency and effectiveness in the economic space, allowing all agents to maximize benefits, which ultimately impact productivity, price stability, income redistribution, poverty alleviation and employment generation.

Nigeria has since independence faced the arduous task of building strong and enduring institutions as exemplified by unethical business practices, political debauchery, legislative inhibition, inert governance structures and the like, all of which have negatively impacted the performance of the economy. It is apposite to say that there is an inextricable link between the quality of a country's institutions and the extent to which policy measure can meet set targets and ultimately, the pace of national development. Consequently, the activities of institutions can affect growth and development through a variety of ways including their effects on how the markets function, the nature and extent of competition, socio-economic 
policies, rule of law, business environment, security, investment, among others. This is because various political and legal agents of the state such as the ministries, departments and agencies, in addition to the executive, legislature and judiciary, can act as restraints on economic agents and thus better serve the interest of the public. This they can do by having the capacity to resist and discourage breaches of agreed procedures and processes and when necessary to question the existing order, thereby increasing the national capacity to maximise the use of scarce resources.

Despite the presence of many political, social, financial and economic institutions and their associated mechanisms in Nigeria, macroeconomic performance of the desirable type (such as high growth rate, high level of employment, poverty reduction, and price stability) has not been attained. The implication is that institutional capacity in Nigeria is low and has not been developed and translated into desirable macroeconomic policy objectives. Consequently, the high unemployment and poverty levels in the country are not in tandem with the prediction of theory, given that high institutional capacity is positively correlated with various macroeconomic performance indices. It is therefore pertinent to question the extent to which institutional capacity in Nigeria has succeeded, given the plethora of challenges facing the country and the rather dismal performance over the years as encapsulated in various human development indicators.

From the foregoing, the aim of the paper is to evaluate the impact of institutional capacity on Nigeria's macroeconomic performance within a multivariate vector error correction framework. Following the introduction, the structure of the paper is as follows. Section 2 deals with literature review. Methods and materials are covered in Section 3. Empirical results are presented and discussed in Section 4. The study is concluded in Section 5.

\section{Literature Review}

\subsection{Meaning, Types and Determinants of Institutions}

According to North (1990), institutions are "the humanly devised constraints that structure political, economic and social interaction." Thus, it can be said that institutions shape and define the rules which shape opportunities and incentives in an economic system.

Different types of institutions have been identified and distinguished in the literature. In the view of North (1990), there are informal institutions or rules (such as traditions and taboos) and formal institutions or rules (such as constitutions and laws). A distinction can be made between economic and political institutions. While economic institutions shape the rules of the economic game which may influence investment and production decisions, contracting and property rights, political institutions shape the rules of the political game through its impact on the distribution of political power.

In the literature, institutions, economic policy and geography are considered the three most important determinants of a country's economic performance. Hence three hypotheses have been maintained and are extant in the literature, i.e. the institutions hypothesis, the policy 
hypothesis and the endowment hypothesis. The premise of the institutions hypothesisis is that the quality of institutions works better than both geography and policy in the determination of a country's level of development (Easterly \& Levine 2003; Basu, 2008). The proponents of the policyhypothesis advocate that what is responsible for faster economic growth is efficient resource allocation induced by economic policy (Edwards, 1998; Dollar \&Kraay, 2003). The contention of the endowment hypothesis is that geography/biogeographic or climatic conditions account for differences in economic performance across countries (Gallup et al, 1998; Acemoglu et al, 2001).

Other determinants of institutional quality and capacity have been identified in the literature. They include the legal structure inherited by colonized countries (La Porta et al, 1999); the presence of natural resources which induces rent-seeking opportunities and consequently influences the nature, quality and capacity of institutions (Chong \&Zanforlin, 2000); and the extent of a country's openness (Islam \& Montenegro, 2002). One very interesting finding is that linking average national intelligence quotient (IQ) to government institutions, with the effect that average IQ positively impacts government institutions (Kalonda-Kanyama\&Kodila-Tedika, 2012).

\subsection{Institutions and Macroeconomic Performance}

The centrality of institutions in modern states is generally recognized in terms of the benefits derived by individuals and how resources are employed in the improvement of their social and economic conditions. The overriding conclusion in empirical studies is that only institutions of good quality are capable of promoting development and thus macroeconomic performance (Easterly \& Levine, 2003). Although it has been difficult to provide an overriding definition of good institutions, what appears to underlie scholarly discourses is that institutions are of good quality if they positively impact the quality of life enjoyed by the citizens of a country (Kaufmann et al., 2004; Huther \& Shah, 2005). Investigations by economists have yielded robust association between institutions and economic wellbeing (Knowles \& Weatherston, 2007). One of the major conclusions in the literature is that institutional quality is an important precondition for growth (Bekaert et al., 2005).

The imperatives of institution to the economic development of a country have been extensively dissected in the literature. Many scholars are of the view that certain cultural traits, social traditions and habits account for the difference to be found between the poorest and the richest countries as reflected in the quality of the shared rules and the institutions which ensure optimal coordination among economic agents. Consequently, they agree that in free economies where there are fewer restraints on economic freedom, such countries tend to experience prosperity, whereas in societies where restraints are pervasive and dominant, they inhibit the growth process and generally tend towards impoverishment of the people (Kasper \& Streit, 1998).

From the foregoing, it can be seen that the relevance of institutions is readily discerned from their roles in protecting the independence of the individual in decision making, in addition to providing the lubricant or infrastructure such as the skills, knowledge, natural resources, and capital which are crucial to the development process. Good and quality institutions tend to 
enhance individual interaction in society and solidify shared values, trust and confidence in all economic, social and political dealings. Due to the incredibly complex nature and dynamics of the modern world, good institutions readily come to play in exploiting the division of labour and drawing on the specialized knowledge and know-how possessed by a matrix of individuals and countries, the lack of which engenders little or no experimentation and innovation, rendering growth and development elusive (Scully, 1992).

The role of property rights and the rule of law in enhancing economic opportunities have particularly received attention in the literature of institution-growth nexus and is mostly associated with North (1990). Here, emphasis is placed on the rules of the game in a society and how conducive they are to desirable economic behavior, to the extent that qualitative institutions are believed to engender an incentive structure capable of reducing uncertainty, thereby promoting efficiency which is a key ingredient in inducing growth and development.

It is generally agreed that the higher the quality of the institution, the more likely it is for economic development to be achieved. In fact, differences in the rate of development across countries have been associated with the differences in the quality of institutions (Rodrik et al., 2002). Even in the analysis of openness or integration, the quality of a country's institutions has been found to be an important determinant. According to Ranjay and Lee (2003), the enforcement of contracts, which is an aspect of institution, can impact the volume of international trade. Consequently, imperfect enforcement of contracts can reduce the volume of trade in products for which quality is an important issue. In addition, the studies conducted by Anderson and Marcoullier (2002) show that the volume of bilateral trade is positively influenced by institutional quality of the trading partners. Levchenko (2004) maintains that differences in institutional quality can be a source of comparative advantage, when he finds that institutional differences across countries are important determinants of trade patterns.

From the foregoing, it is not of place to emphasize that institutions of high quality are growth and development stimulants. This is because high-quality institutions are impartial in implementing laws and policies, thus helping to foster the rules and procedures, while promoting the creation of innovative systems for economic growth and development (Chousa et al., 2005; Rothstein \&Teorell, 2008). For example, Bensyishay and Betancourt (2010), investigating the direct role of civil liberties and its impact on economic activity find that the property rights institutions sub-category has significant impact on long term economic growth. On the part of social institutions as an agent of growth and development, Fao (2008) investigates the link between social institutions and the broader aspects of human development and finds that non-discrimination against women, ethnic, religious and caste minorities, and conformity to norms of equality have significant effects on health outcomes, implying that these factors are proximate determinants of economic growth, such that in countries where they are relatively higher, they achieve significantly higher levels of income per capita in the long-run. 


\section{Methodology}

\subsection{Sources and Description of Data}

Annual data for the period 1961 to 2011 was employed in the study. The use of annual data was favoured due to their availability throughout the study period. The data was obtained from the Statistical Bulletin of the Central Bank of Nigeria. One proxy each for fiscal and monetary policy was used, in addition to the proxy for institutional capacity and the target variable is real economic growth.

Many variables and indicators have been identified as reflective of the level of progress in several key areas of institutions. The paper uses contract intensive money (CIM) developed by Clague et al. $(1996,1999)$ which was originally designed to measure property rights. The argument of the scholars followed the Williamson (1995) hypothesis that the existence of long-term contracts is a sign of a developed economy. This is underpinned on the fact that it shows confidence that people have in dealing with other parties, so that if this trust existed, investment would be higher. It follows that if this is the case, this would be reflected in a high proportion of the money supply being held in financial institutions, which indicates the existence of long term, high value transactions taking place. The conclusion therefore that can be reached is that the greater the proportion of money held in currency, the less faith people have in making these transactions. It is therefore important to assert that based on this view, people can be observed to hold more of their wealth in currency in periods of uncertainty, indicating lack of faith or confidence in the capacity of institutions. The higher the value of CIM, the greater is the reliance on or preference for long-term contracts. The use of this indicator is justified in that many empirical studies have found significant relationship between financial development and economic growth (Levine 1998; Bencivenga \& Smith, 1991; De Gregorio \& Guidotti, 1995; Greenwood \& Jovanovic, 1990). In addition, there is a ready availability of data on contract intensive money across countries and regions over a long period of time. CIM is computed as the difference between broad money supply (M2) and currency held outside circulation as a proportion of broad money supply.

For the study, government expenditure was taken as a measure of fiscal policy; money supply was taken as a measure of monetary policy, while contract intensive money was used as a proxy for institutional capacity. Money Supply (M1), Government Expenditure (GE) and real Gross Domestic Product (RGDP) were transformed into logarithms while institutional capacity was in nominal terms.

\subsection{Model Specification}

The Vector Error Correction Model (VECM) is used in the study. It has been demonstrated that when a set of variables are cointegrated and of the order I (1), the short-run analysis of the system should incorporate error correction term with a view to modelling the adjustment for the deviation from its long-run equilibrium (Engle \& Granger, 1987). Consequently, both the short- and long-run equilibrium estimates are contained in the vector error correction model.

The multivariate VECM specifications of the variables used in the study are presented in four 
endogenous variables, i.e. Real Gross Domestic Product (RGDP), Government Expenditure (GE), Money Supply (M1) and Institutional capacity (IC) and presented in equations 1 through 4.

$$
\begin{aligned}
& \Delta R G D P_{t}=\gamma_{1}+\delta_{11} E C M_{t-1}+\sum_{i=1}^{k-1} \delta_{11 i} \Delta R G D P_{t-i}+\sum_{i=1}^{k-1} \delta_{12 i} \Delta G E_{t-i}+\sum_{i=1}^{k-1} \delta_{13 i} \Delta M 1_{t-i}+\sum_{i=1}^{k-1} \delta_{14 i} \Delta I C_{t-i}+\varepsilon_{1 t} \ldots(1) \\
& \Delta G E_{t}=\gamma_{2}+\delta_{21} E C M_{t-1}+\sum_{i=1}^{k-1} \delta_{21 i} \Delta R G D P_{t-i}+\sum_{i=1}^{k-1} \delta_{22 i} \Delta G E_{t-i}+\sum_{i=1}^{k-1} \delta_{23 i} \Delta M 1_{t-i}+\sum_{i=1}^{k-1} \delta_{24 i} \Delta I C_{t-i}+\varepsilon_{2 t} \ldots(2) \\
& \Delta M 1_{t}=\gamma_{3}+\delta_{31} E C M_{t-1}+\sum_{i=1}^{k-1} \delta_{31 i} \Delta R G D P_{t-i}+\sum_{i=1}^{k-1} \delta_{32 i} \Delta G E_{t-i}+\sum_{i=1}^{k-1} \delta_{33 i} \Delta M 1_{t-i}+\sum_{i=1}^{k-1} \delta_{34 i} \Delta I C_{t-i}+\varepsilon_{3 t} . .(3) \\
& \Delta I C_{t}=\gamma_{4}+\delta_{41} E C M_{t-1}+\sum_{i=1}^{k-1} \delta_{41 i} \Delta R G D P_{t-i}+\sum_{i=1}^{k-1} \delta_{42 i} \Delta G E_{t-i}+\sum_{i=1}^{k-1} \delta_{43 i} \Delta M 1_{t-i}+\sum_{i=1}^{k-1} \delta_{44 i} \Delta I C_{t-i}+\varepsilon_{4 t} . .(4)
\end{aligned}
$$

In equations 1 through 4 , the left hand side is expressed in first differences, while the right-hand side has an optimum lagged-differences of the four variables, in addition to the one-period lagged error term of the cointegrating equation (i.e. $\mathrm{ECM}_{\mathrm{t}-1}$ ). The intercept terms are denoted by $\gamma_{1}, \ldots \gamma_{4}$ while the disturbance terms are denoted by $\varepsilon_{1 \mathrm{t}}, \ldots \varepsilon_{4 \mathrm{t}}$.

There are two sources of causation in a VECM framework i.e. one originating from the ECM term and the other from the lagged dynamic terms. Consequently, two causality tests are carried out, i.e. the short-run Granger non-causality test and the long-run causality. The short-run Granger non-causality test is carried out through the strong exogeneity test, while the long run causality is executed through the weak exogeneity test. In the present investigation, the causality tests are carried out through the Wald test and are used in analyzing of the short-run and long-run causality between Nigeria's institutional capacity and macroeconomic performance.

\subsection{Model Estimation Procedure}

The stability properties of the variables employed in the study were first examined in order to determine their order of integration. This is crucial in that it facilitates the determination of the appropriate econometric framework to be adopted for analysis.

Three unit root tests were used in the present study, i.e. the Augmented Dickey-Fuller (ADF), the Phillips-Perron (PP) and the Kwiatkowski-Phillips-Schmidt-Shin (KPSS). The choice of the three unit root tests is to allow for robustness and comparison. Generally, the PP unit root test is considered to have a greater reliability than the ADF due to its robustness in the midst of serial correlation and hetersokedasticity; however, because it has been shown that both ADF and PP suffer from high size distortion (Volgelsang \& Perron, 1998), it was considered appropriate to include the Kwiatkowski-Phillips-Schmidt-Shin (KPSS) test.

The test for unit root for a variable $\mathrm{N}$ is carried out using the following specification: 
$\Delta N_{t}=\beta_{0}+\beta_{1 t}+\beta_{2} N_{t-1}+\sum_{i=0}^{p} \psi_{i} \Delta N_{t-i}+\varepsilon_{t}$

where, $\beta_{0}, \beta_{1}, \beta_{2}$ and $\psi_{1}, \ldots \psi_{\mathrm{p}}$ are parameters to be estimated, and $\varepsilon_{\mathrm{t}}$ is the disturbance term assumed to be normally and identically distributed.

Test of cointegration follows the unit root test using the Johansen (1988) methodology, after which the investigation of short-run and long-run causality between real economic growth and institutional capacity was carried out through the Vector Error Correction Model (VECM). To test for long-run non-causality, the null hypothesis that the coefficient of $\mathrm{ECM}_{\mathrm{t}-1}$ is zero is tested in each of the equations, to determine whether the variables on the right-hand side Granger-cause the variable on the left-hand side. Five short-run Granger causality tests are performed in equations 1 through 4, by setting the coefficients of all order-lagged differences of each of the variables on the right-hand side equal to zero. In equation (1) for example, to test for short-run non-causality from Government Expenditure (GE) to Real Gross Domestic Product (RGDP), the coefficients of the lagged differences of the GE are all set equal to zero. The same is done with respect to other variables in the system such as M1 and IC on RGDP.

To complete the test of causality, an overall causality (strong exogeneity) is executed in each equation. To do this, all the coefficients of each right-hand side variable including the coefficient of the error correction term (ECM) are jointly set equal to zero. In addition to the causality tests, the generalized impulse response function and variance decomposition relating to the two major variables of interest, i.e. Real Gross Domestic Product (RGDP) and Institutional Capacity (IC) are presented and analysed in the present study. With the variance decomposition, it is easy to capture the relative degree of exogeneity and endogeneity of the variables in the VAR system while the employment of impulse response functions captures the overall dynamics of the responses by the variables to the shocks in the system.

\section{Results and Discussion}

The unit root test results are presented in Table 1. 
Table 1. Unit Root Test Results

\begin{tabular}{|c|c|c|c|c|c|c|}
\hline \multirow[b]{2}{*}{ Variable } & \multicolumn{2}{|c|}{ ADF } & \multicolumn{2}{|c|}{ PP } & \multicolumn{2}{|c|}{ KPSS } \\
\hline & Constant & $\begin{array}{c}\text { Constant \& } \\
\text { trend }\end{array}$ & Constant & $\begin{array}{l}\text { Constant } \\
\text { and trend }\end{array}$ & Constant & $\begin{array}{c}\text { Constant \& } \\
\text { trend }\end{array}$ \\
\hline RGDP & -1.162012 & -1.301852 & -1.181277 & -1.315125 & $0.870593^{*}$ & $0.200695^{* *}$ \\
\hline GE & 6.741907 & 2.059360 & 6.134944 & 1.134778 & $0.821066^{*}$ & $0.243701^{*}$ \\
\hline M1 & 0.481049 & -3.001955 & 0.925456 & -2.608146 & $0.947006^{*}$ & $0.123386^{* * *}$ \\
\hline IC & -0.582998 & -1.362471 & -0.709968 & -1.584972 & $0.667000^{* *}$ & $0.120544^{* * *}$ \\
\hline$\Delta$ RGDP & $-6.434244^{*}$ & $-6.455390^{*}$ & $-6.421071^{*}$ & $-6.451864^{*}$ & 0.193341 & 0.093849 \\
\hline$\Delta \mathrm{GE}$ & $-2.740463^{* * *}$ & $-5.591567^{*}$ & $-7.934448^{*}$ & $-11.63206^{*}$ & 0.781070 & 0.144930 \\
\hline$\Delta \mathrm{M} 1$ & $-4.781679^{*}$ & $-4.819225^{*}$ & $-4.769898^{*}$ & $-4.769176^{*}$ & 0.182980 & 0.069951 \\
\hline$\Delta \mathrm{IC}$ & $-6.524016^{*}$ & $-6.447502^{*}$ & $-6.543719^{*}$ & $-6.470944^{*}$ & 0.111878 & 0.112141 \\
\hline
\end{tabular}

Note: For ADF and PP, the null hypothesis is that the variable has a unit root whereas for KPSS, the null hypothesis is that the variable is stationary. *,**and *** denote order of integration at $1 \%, 5 \%$ and $10 \%$ respectively. Source: Authors' computations.

Results in Table 1 suggest that all the variables are non-stationary in levels but stationary in first differences. All three tests of unit roots lead to the same conclusion and are thus consistent. Consequently, as the variables are integrated of the same order and are I(1), a test of cointegration is carried out followed by the estimation of the Vector Error Correction Model.

The results of lag order selection criteria for the estimated model are presented in Table 2.

Table 2. Lag Order Selection Criteria

\begin{tabular}{ccclclc}
\hline Lag & LogL & LR & FPE & AIC & SC & HQ \\
\hline 0 & -274.7321 & NA & 1.664390 & 11.86094 & 12.01840 & 11.92019 \\
1 & -1.298041 & 488.6907 & $2.92 \mathrm{e}-05$ & 0.906300 & $1.693596^{*}$ & $1.202565^{*}$ \\
2 & 19.85051 & $34.19766^{*}$ & $2.38 \mathrm{e}-05^{*}$ & $0.687212^{*}$ & 2.104347 & 1.220489 \\
3 & 30.24096 & 15.03299 & $3.15 \mathrm{e}-05$ & 0.925916 & 2.972888 & 1.696206 \\
4 & 49.80693 & 24.97783 & $2.92 \mathrm{e}-05$ & 0.774173 & 3.450982 & 1.781474 \\
\hline
\end{tabular}

*indicates lag order selected by the criterion

FPE: Final prediction error

AIC: Akaike information criterion

SC: Schwarz information criterion

HQ: Hannan-Quinn information criterion

Source: Authors' computations.

From Table 2, LR, FPE and AIC chose lag 2 while SC and HQ chose lag 1. Using 2 lags in the estimation generally produced a VAR which does not satisfy the stability condition, as one of the roots lies outside the unit circle. At lag 1, the stability condition is satisfied (see Panel B of Table 1B in the Appendix). Consequently, the highest lag employed in the VECM is 1 , following SC and HQ lag selection criteria. 
The results of the cointegraton test are presented in Table 3.

Table 3. Johansen Cointegration Test Results

\begin{tabular}{|c|c|c|c|c|c|c|}
\hline \multicolumn{2}{|c|}{ Hypothesis } & \multirow{2}{*}{$\begin{array}{l}\text { Eigen } \\
\text { value }\end{array}$} & \multirow{2}{*}{$\lambda_{\max }$} & \multirow{2}{*}{$\begin{array}{c}5 \% \\
\text { critical } \\
\text { value }\end{array}$} & \multirow{2}{*}{$\lambda_{\text {trace }}$} & \multirow{2}{*}{$\begin{array}{c}5 \% \\
\text { critical } \\
\text { value }\end{array}$} \\
\hline Null & Alternative & & & & & \\
\hline $\mathrm{r}=0$ & $\mathrm{r} \geq 1$ & 0.586999 & $43.33092^{*}$ & 27.58434 & $69.48473^{*}$ & 47.85613 \\
\hline$r \leq 1$ & $r \quad \geq 2$ & 0.355592 & $21.53175^{*}$ & 21.13162 & 26.15381 & 29.79707 \\
\hline$r \leq 2$ & $r \geq 3$ & 0.089647 & 4.602209 & 14.26460 & 4.622065 & 15.49471 \\
\hline$r \leq 3$ & $\mathrm{r} \geq 4$ & 0.000405 & 0.019856 & 3.841466 & 0.019856 & 3.841466 \\
\hline
\end{tabular}

$\mathrm{r}$ indicates the number of cointegrating vectors. *Indicates rejection of the null hypothesis at $5 \%$ level of significance.

Source: Authors' computations.

Results in Table 3 suggest that the maximal eigenvalues and trace test statistics indicate that the hypothesis of no cointegration among the variables is rejected at the $5 \%$ significance level. From the result, there is at least one cointegrating vector among the variables of interest based on both the maximal eigenvalues and trace test statistics $\left(\lambda_{\max }\right.$ and $\left.\lambda_{\text {trace }}\right)$. While the trace test statistics indicate one cointegrating vector, the maximum eigenvalue tests indicate two cointegrating vectors. Although the maximum eigenvalue test has been shown to perform better than the trace test statistics (Patterson, 2000), there is only one cointegrating vector from the Johansen cointegration framework, so that only normalisation restriction is imposed in the present study on RGDP to examine the long-run causality between institutional capacity and macroeconomic performance. Due to the existence of long-term equilibrium relationships among non-stationary variables in the system, the use of the VECM is justified.

The long-run coefficients of the cointegrating vector normalised on RGDP is presented in Table 4.

Table 4. Long-Run Coefficient of the Cointegrating Vector

\begin{tabular}{cccccc}
\hline RGDP & CONSTANT & GE & M1 & IC & Loading factor \\
& -31.99509 & $0.117714^{* * *}$ & $24.59192^{* *}$ & $-148.6008^{* *}$ & $-0.000778^{*}$ \\
& & $(1.96565)$ & $(2.35518)$ & $(-2.02631)$ & {$[0.00053]$} \\
\hline
\end{tabular}

Diagnostic Tests

$\chi_{\text {LM }}^{2}=13.52571(0.6340)$

JB $\chi_{\text {Normality (2df) }}^{2} 0.192599(0.9082)$

$\chi_{\text {Heteros }}^{2}($ with cross terms) $=197.8358(0.5300)$

$\chi_{\text {Heteros }}^{2}$ (without cross terms) $=102.1833(0.4206)$

$(*),(* *)$ and $(* * *)$ indicate $1 \%, 5 \%$ and $10 \%$ level of significance respectively. Figures in parentheses are $\mathrm{t}$-values and the figure in square bracket is standard error.

Source: Authors' computations. 
The cointegration equation results in Table 4 indicate that GE is positively related to RGDP in the long run. The implication is that government expenditure in Nigeria supports positive growth in the economy and is statistically significant at the $10 \%$ level.

The result of the relationship between money supply and RGDP indicates that it is positive and statistically significant at the 5\% level. This is consistent with economic theory in that an increase in the supply of money will improve the level of output due to the increase in investment originating from lowered interest rates. The result tends to suggest that macroeconomic performance in terms of aggregate output is likely to be improved using monetary instruments.

In addition, the cointegration equation results indicate that RGDP is negatively related to IC in the long run and statistically significant at the 5\% level. It is expected that as institutional capacity improves, real growth and thus macroeconomic performance improves. The explanation is that with increase in institutional capacity, efficiency and effectiveness are engendered in many sectors of the economy, due to the discipline imposed by institutional capacity. Consequently, institutional capacity improves in terms of discharge of property rights, good and effective governance structure and the like, all of which send positive signals to economic agents. The overall results are that production and consumption take an upward trend. However, this result is hardly surprising, given that the nature and dynamics of institutions in the Nigerian economy have had little if any positive impact on real output. In a nutshell, there have been increases in real growth in Nigeria while the quality of institutions as encapsulated in various indicators (such as corruption perception index and governance index) has been progressively deteriorating. Consequently, that there is a negative relationship between institutional capacity and macroeconomic performance as captured by real GDP is not out of place. It must be remembered that Nigeria's real GDP can be said to be aided more by external forces in terms of the production of crude oil, the price of which is determined at the international market than by prevailing local conditions, many of which are not growth-supportive (high interest rates, poor and inadequate energy, poor governance and the like), so that local sectors such as manufacturing, agriculture and non-oil mining have been badly hit over the years, exacerbated mostly after the introduction of the Structural Adjustment Progrmmme (SAP) in the mid 1980s. Prominent in Nigeria's chequered history is the yawning gap in institutional development. Institutional arrangements, encompassing the paraphernalia and organs of state, including policy making and its associated procedures and processes, provide the leverage for planning, deploying scarce resources, including effective implementation of projects. When institutions of restraint are weak, it directly impacts on respect for contractual obligations as well as the ability to enforce them. For example, the lack of an efficient and reliable legal system is capable of reducing the level of credits in commercial transactions, thereby increasing the cost of doing business, and can promote corruption. The legal system for instance as an effective agent of restraint, is far from being efficient and reliable in Nigeria and therefore cannot promote the use of assets as marketable collateral.

Misspecification tests for serial correlation, normality and heteroskedasticity were carried out on the estimated model. The Lagrange Multiplier tests show that there is no serial correlation 
at the chosen lag 1, in that the LM statistic of 13.52571 and its associated probability value of 0.6340 indicate the non-rejection of the null hypothesis of no serial correlation of the residuals. In addition, the model passes the normality test through the Jarque-Bera (JB) statistics which at four components and 2 degree of freedom is 0.192599 with a probability value of 0.9082 , indicating that the residuals are multivariate normal. It must be remembered that the failure of normality test is not a serious problem under the Johansen cointegrating framework, as no assumption about the distribution error term is made under the procedures of reduced rank simultaneous least squares (Gonzalo, 1994). The estimated model also passes the residual heteroskedasticity tests both with and without cross terms, with the Chi-square and its related probability value of the former being $197.8358(0.5300)$ while the value of the latter is $102.1833(0.4206)$, indicating that the residuals are homoskedastic. The loading factor in the estimated model is negative and statistically significant and thus follows a priori expectations.

The VECM causality test results are presented in Table 5.

Table 5. VECM-Granger Non Causality Test

Panel A: Short Run Non-Causality and Strong Exogeneity Test Results

\begin{tabular}{ccc}
\hline Hypothesis & Short Run Non-Causality & Strong Exogeneity \\
\hline Ho: $\Delta \mathrm{GE} \rightarrow \Delta \mathrm{RGDP}$ & $\delta_{12 \mathrm{i}}=0$ & $\delta_{11}=\delta_{12 \mathrm{i}}=0$ \\
$\chi^{2}$ & $0.536540(1)$ & $1.492878(2)$ \\
\hline Ho: $\Delta \mathrm{RGDP} \rightarrow \Delta \mathrm{GE}$ & $\delta_{11 \mathrm{i}}=0$ & $\delta_{11 \mathrm{i}}=\delta_{21}=0$ \\
$\chi^{2}$ & $0.000366(1)$ & $35.41426(2)^{*}$ \\
\hline Ho: $\Delta \mathrm{M} 1 \rightarrow \Delta \mathrm{RGDP}$ & $\delta_{13 \mathrm{i}}=0$ & $\delta_{13 \mathrm{i}}=\delta_{11}=0$ \\
$\chi^{2}$ & $0.281657(1)$ & $3.704526(2)$ \\
\hline Ho: $\Delta \mathrm{RGDP} \rightarrow \Delta \mathrm{M} 1$ & $\delta_{11 \mathrm{i}}=0$ & $\delta_{11 \mathrm{i}}=\delta_{31}=0$ \\
$\chi^{2}$ & $0.000366(1)$ & $0.101149(2)$ \\
\hline Ho: $\Delta \mathrm{IC} \rightarrow \Delta \mathrm{RGDP}$ & $\delta_{14 \mathrm{i}}=0$ & $\delta_{14 \mathrm{i}}=\delta_{11}=0$ \\
$\chi^{2}$ & $1.236393(1)$ & $1.717831(2)$ \\
\hline Ho: $\Delta \mathrm{RGDP} \rightarrow \Delta \mathrm{IC}$ & $\delta_{11 \mathrm{i}}=0$ & $\delta_{11 \mathrm{i}}=\delta_{41}=0$ \\
$\chi^{2}$ & $0.000366(1)$ & $3.473045(2)$ \\
\hline Ho: $\Delta \mathrm{IC} \rightarrow \Delta \mathrm{GE}$ & $\delta_{14 \mathrm{i}}=0$ & $\delta_{14 \mathrm{i}}=\delta_{21}=0$ \\
$\chi^{2}$ & $1.236393(1)$ & $34.23591(2) *$ \\
\hline Ho: $\Delta \mathrm{GE} \rightarrow \Delta \mathrm{IC}$ & $\delta_{12 \mathrm{i}}=0$ & $\delta_{12 \mathrm{i}}=\delta_{41}=0$ \\
$\chi^{2}$ & $0.536540(1)$ & $3.932578(2)$ \\
\hline Ho: $\Delta \mathrm{IC} \rightarrow \Delta \mathrm{M} 1$ & $\delta_{14 \mathrm{i}}=0$ & $\delta_{14 \mathrm{i}}=\delta_{31}=0$ \\
$\chi^{2}$ & $1.236393(1)$ & $1.269701(2)$ \\
\hline Ho: $\Delta \mathrm{M} 1 \rightarrow \Delta \mathrm{IC}$ & $\delta_{13 \mathrm{i}}=0$ & $\delta_{13 \mathrm{i}}=\delta_{41}=0$ \\
$\chi^{2}$ & $0.281657(1)$ & $3.618641(2)$ \\
\hline & &
\end{tabular}


Panel B: Long-run Causality (Weak Exogeneity) Test Results

\begin{tabular}{l} 
RGDP (Ho: $\left.\delta_{11}=0\right)$ \\
$\chi^{2}(1): 1.488315$ \\
\hline GE (Ho: $\left.\delta_{21}=0\right)$ \\
$\chi^{2}(1): 21.29815^{*}$ \\
\hline M1 (Ho: $\left.\delta_{31}=0\right)$ \\
$\chi^{2}(1): 0.101043$ \\
IC (Ho: $\left.\delta_{41}=0\right)$ \\
$\chi^{2}(1): 3.451556^{* * *}$ \\
\hline
\end{tabular}

${ }^{*},{ }^{* *}$ and ${ }^{* * *}$ represent $1 \%, 5 \%$ and $10 \%$ level of significance respectively. The numbers in parenthesis indicate the degree of freedom for the chi-square $\left(\chi^{2}\right)$.

Authors' computations.

The short-run non-causality results indicate that other variables in the system do not Granger-cause the related variable. The strong exogeneity (i.e. the overall causality in the system) shows that the null hypothesis that RGDP does not Granger-cause GE; and that IC does not Granger-cause GE is rejected at the 1\% level of significance.

In Panel B of Table 5, the long-run causality shows evidence of bidirectional causality between institutional capacity (IC) and other variables in the system and it is statistically significant at the 10\% level. The null hypothesis that GE does not Granger-cause other variables in the system is rejected and is statistically significant at the $1 \%$ level, thus confirming the bidirectional causality between government expenditure (GE) and other variables in the system.

\subsection{Variance Decomposition and Impulse Response Function}

The analyses of variance decomposition and impulse response function in the present study are focused on institutional capacity and macroeconomic performance, occasioned by the need to examine the long-run relationship between them. The aim of using impulse response function is to trace the time path of structural shocks in the VAR system. Two popular frameworks commonly employed are the cholesky decomposition and the generalized impulse response function. The former is often criticized because it is quite sensitive to the ordering of the variables in the system. The study therefore adopts the Generalised Impulse Response Function (GIRF), a method that is invariant to the ordering of the variables in the VAR system. The analysis of the impulse response function is executed at two levels. These are the unrestricted VAR level and the Vector Error Correction (VEC) level. Consequently, the unrestricted level VAR serves as a complement to the second VEC level.

The variance decomposition for the estimated VEC model is presented in Table 6. 
Table 6. Variance Decomposition at VEC Level

\begin{tabular}{|c|c|c|c|c|c|}
\hline \multirow{2}{*}{ Horizon } & \multicolumn{5}{|c|}{ 6.1: Variance Decomposition of Macroeconomic Performance (RGDP) } \\
\hline & \multicolumn{2}{|c|}{ S.E. $\quad$ RGDP } & \multirow{2}{*}{$\begin{array}{c}\text { GE } \\
0.670514\end{array}$} & \multirow{2}{*}{$\begin{array}{c}\text { M1 } \\
2.477127\end{array}$} & $\mathrm{IC}$ \\
\hline 2 & 0.195660 & 96.50122 & & & 0.351138 \\
\hline 4 & 0.287395 & 92.23006 & 0.920760 & 5.881767 & 0.967412 \\
\hline 6 & 0.357742 & 90.50908 & 0.917745 & 7.038254 & 1.534921 \\
\hline 8 & 0.415811 & 89.77591 & 0.818867 & 7.249560 & 2.155659 \\
\hline \multirow[t]{2}{*}{10} & 0.466140 & 89.37838 & 0.697240 & 7.054559 & 2.869823 \\
\hline & \multicolumn{5}{|c|}{ 6.2: Variance Decomposition of Government Expenditure (GE) } \\
\hline 2 & 19.37378 & 0.047548 & 98.14300 & 1.780735 & 0.028715 \\
\hline 4 & 28.40301 & 0.029222 & 93.65428 & 5.206899 & 1.109601 \\
\hline 6 & 37.63623 & 0.058797 & 87.09221 & 9.044584 & 3.804408 \\
\hline 8 & 47.91110 & 0.111083 & 80.00571 & 12.57126 & 7.311949 \\
\hline \multirow[t]{2}{*}{10} & 59.48890 & 0.171224 & 73.26078 & 15.57574 & 10.99225 \\
\hline & \multicolumn{5}{|c|}{ 6.3: Variance Decomposition of Money Supply (M1) } \\
\hline 2 & 0.114474 & 0.559809 & 9.817985 & 89.62020 & 0.002003 \\
\hline 4 & 0.186022 & 0.921184 & 10.11997 & 88.93987 & 0.018972 \\
\hline 6 & 0.240824 & 1.051576 & 10.27455 & 88.65119 & 0.022690 \\
\hline 8 & 0.286191 & 1.113547 & 10.38247 & 88.48291 & 0.021071 \\
\hline \multirow[t]{2}{*}{10} & 0.325718 & 1.148956 & 10.47053 & 88.36252 & 0.017986 \\
\hline & \multicolumn{5}{|c|}{ 6.4: Variance Decomposition of Institutional Capacity (IC) } \\
\hline 2 & 0.040535 & 0.162236 & 4.359322 & 8.692173 & 86.78627 \\
\hline 4 & 0.057694 & 0.140187 & 3.446598 & 5.710072 & 90.70314 \\
\hline 6 & 0.070180 & 0.119175 & 2.987231 & 4.409573 & 92.48402 \\
\hline 8 & 0.080223 & 0.104894 & 2.681319 & 3.656256 & 93.55753 \\
\hline 10 & 0.088652 & 0.094083 & 2.438756 & 3.141168 & 94.32599 \\
\hline
\end{tabular}

Source: Authors' computations.

The results of the variance decomposition reported in Table 6 show the contribution of each variable to its own shock in explaining the proportion of forecast error variance at the end of 10 years horizon. In terms of each variable's own shock, the results indicate $89 \%$ for RGDP, $73 \%$ for GE, $88 \%$ for M1 and $94 \%$ for IC respectively. The implication of the results is that institutional capacity is the most exogenous variable in the VAR system, in that at the end of 10 years horizon, macroeconomic performance (RGDP), government expenditure (GE) and money supply (M1) account for only $0.09 \%, 2 \%$ and $3 \%$ of the shocks to institutional capacity respectively. Institutional capacity explains $3 \%$ of the variation in macroeconomic performance (represented by RGDP) while RGDP explains $0.09 \%$ of the variation in institutional capacity. The variance decomposition of macroeconomic performance (RGDP) indicates that $89 \%$ in its variation is due to its own shock, while government expenditure (GE), money supply (M1) and institutional capacity (IC) account for $0.69 \%, 7 \%$ and 3\% respectively. The implication of the results is that institutional capacity is not a major and significant variable explaining the variation in macroeconomic performance in Nigeria. 
The impulse response functions are shown in Figures 1 and 2.
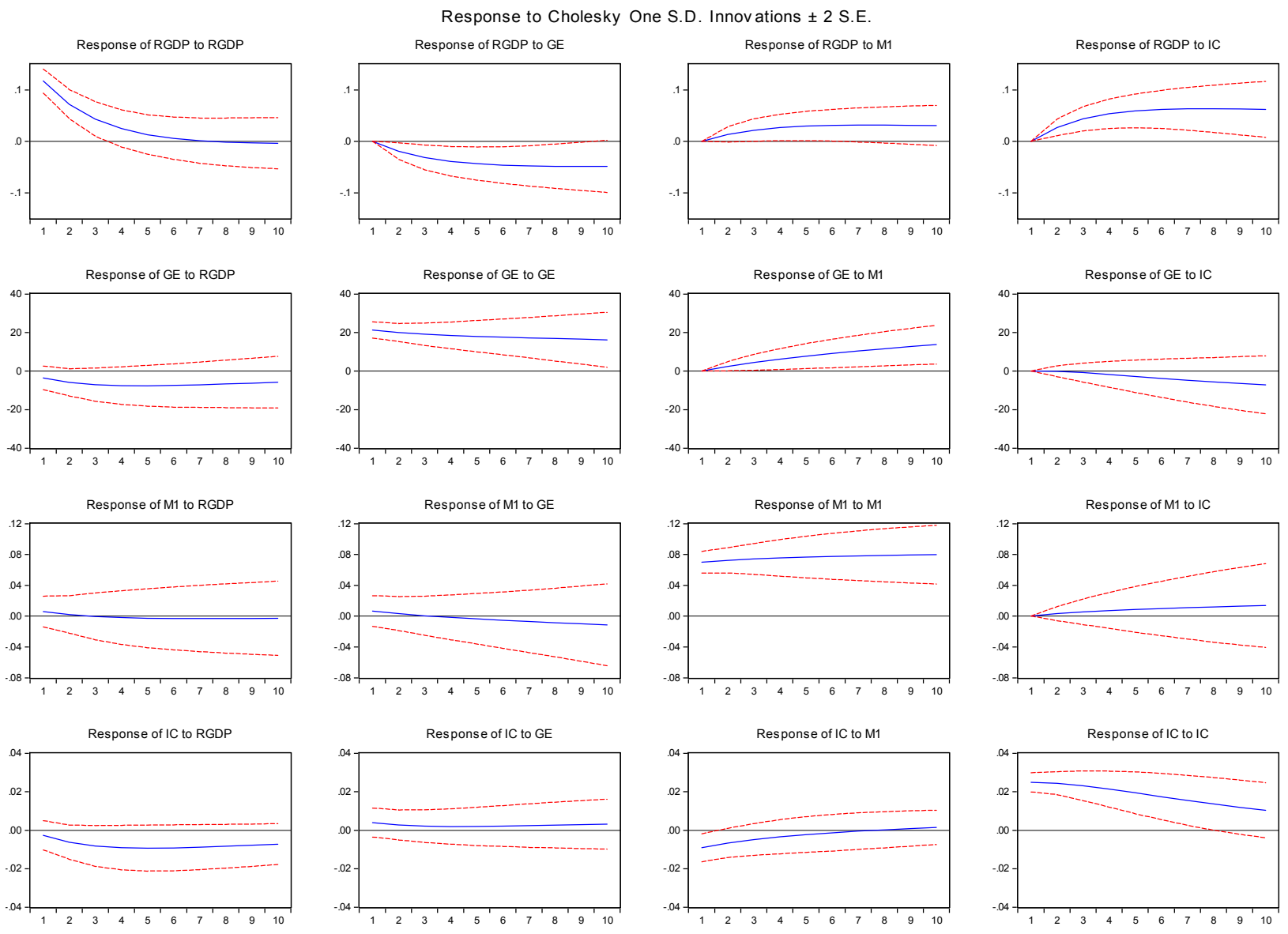

Figure 1. Generalized Impulse Response Function at VAR Level 


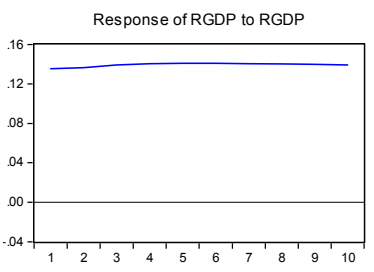

Response to Generalized One S.D. Innov ations
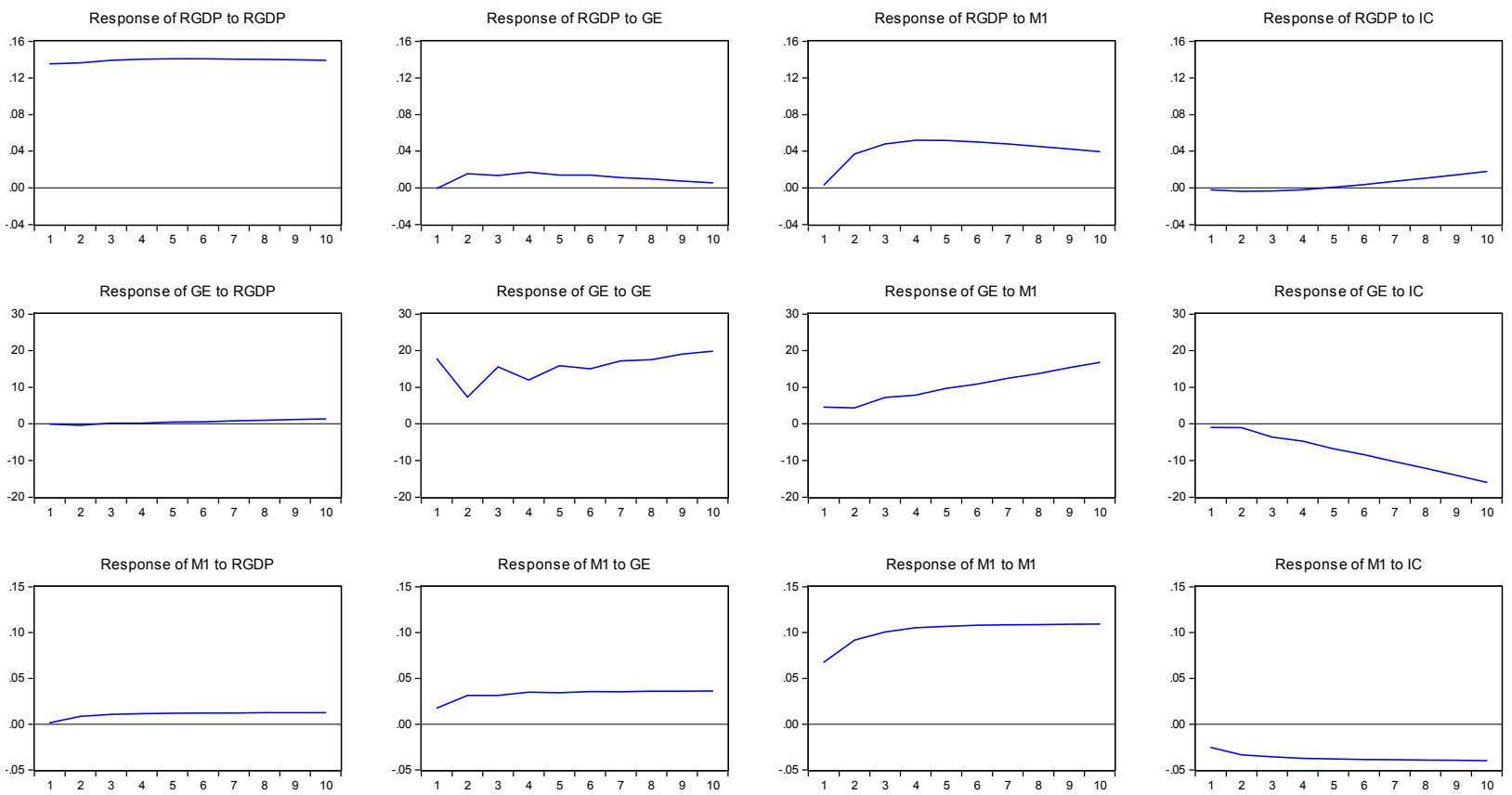

Response of IC to RGDP
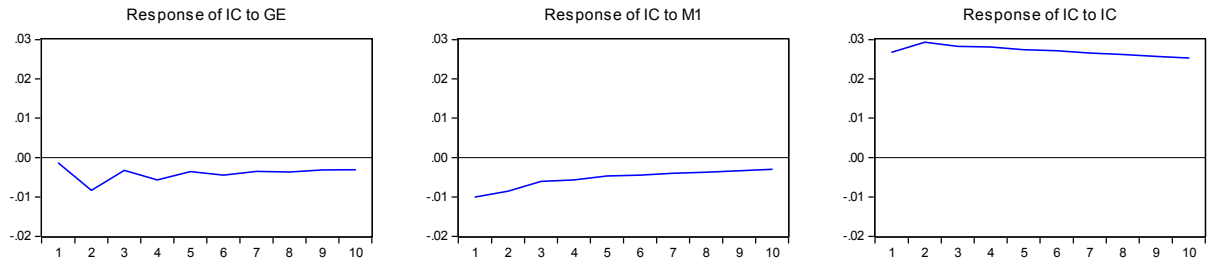

Source: Authors' computations.

Figure 2. Generalized Impulse Response Function at VEC Level

In Figure 1, it can be seen that the responses of RGDP and IC are due to their own shocks. While the response of RGDP to its own shock dies out at the seventh period, the response of IC to its own shock tends to persist up to the tenth period. The response of RGDP to IC continues to remain positive and tends to show some weakening from the sixth period. The response of IC to RGDP is negative from the initial stage and persists up to and even after the tenth period.

The impulse response function at the VEC restriction level is presented in Figure 2. The results indicate that the responses of both RGDP and IC are due to their own shocks. While the response of RGDP to IC remains negative up to the sixth period before showing a positive trend, that of IC to RGDP is negative right from the initial period and eventually dies out at the tenth period. The implication of both the VAR and VEC impulse response functions is that the role played by institutional capacity on macroeconomic performance in Nigeria tends to be marginal and that the nature and quality of institutions tend to undermine the overall performance of the Nigerian economy. 


\section{Conclusion}

This paper aimed at empirically examining the impact of institutional capacity on macroeconomic performance in the Nigerian economy using annual data for the period 1961-2011. To achieve this objective, the study used a multivariate Vector Error Correction Model (VECM) to evaluate the long-run relationships between real gross domestic product (a proxy of macroeconomic performance), government expenditure, money supply and institutional capacity (proxied by contract intensive money). The empirical results show that there is a long-run equilibrium relationship between Nigeria's real gross domestic product, government expenditure, money supply and institutional capacity. The analysis demonstrates that macroeconomic performance is responsive to changes in government spending, money supply and institutional capacity in the long run. The cointegration equation results indicate that macroeconomic performance is negatively related to institutional capacity in the long run and statistically significant at the 5\% level. The result of the relationship between money supply and RGDP indicates that it is positive and statistically significant at the 5\% level, suggesting that macroeconomic performance in terms of aggregate output is likely to be improved using monetary instruments. The results also show that government expenditure is a significant and positively related determinant of RGDP in the long run. There is no evidence of short run causality between institutional capacity and macroeconomic performance. The long-run causality shows evidence of bidirectional causality between institutional capacity and other variables in the system and it is statistically significant. There is also evidence of bidirectional causality between government expenditure and other variables employed in the study. The strong exogeneity (i.e. the overall causality in the system) shows that the null hypothesis that growth does not Granger-cause government expenditure; and that institutional capacity does not Granger-cause government expenditure is rejected at the $1 \%$ level of significance.

Results of the Generalised Impulse Response Functions suggest that one standard deviation innovation on institutional capacity reduces Real GDPin the short, medium and long terms, while results of the Variance Decomposition indicate that a significant variation in Nigeria's macroeconomic performance is not attributable to changes in the capacity of institutions. The implication of both the VAR and VEC level impulse response functions is that although there have been increases in real growth in Nigeria over the years, the quality of institutions as encapsulated in various indicators has been progressively deteriorating. The results of the VECM, generalized impulse response and variance decomposition are thus consistent.

A major finding is that Nigeria's macroeconomic performance is statistically and negatively influenced by changes in the capacity of institutions. This is particularly salient in that the Nigerian economy has not been helped by quality institutions which are expected to provide the impetus for productivity. Noteworthy is the fact that the country has consistently ranked dismally low in various governance and human development indicators. That corruption and other forms of anti-productive tendencies are preponderant in the country is hugely attested to, which may not be unrelated to the incapacity of institutions at all levels.

An overriding implication of the study is that low level of institutional capacity is growth and 
development-damaging. It is clear from the investigation that much of the challenges faced by the country in terms of meeting comparable living and developmental standards in the developed economies can be directly traced to the mismatch between the quality of institutions and various macroeconomic policies. It is evident that economic policies cannot achieve set targets in the midst of low quality institutions. Overall, the goal of achieving high employment and living standards cannot be achieved if the quality of institutions is not given utmost priority by government at all levels.

On the basis of the research findings, it is not in contention that strengthening institutions is a sine qua non for improved macroeconomic performance. Strong institutions are capable of inducing transparency and accountability in both private and public sectors. A robust financial system with strong and virile institutions for example can facilitate the harnessing of its natural resources, promote its competitive advantage and launch it into the league of the frontline economies. At present, there is a weak link between the real sector of the economy and various institutions (political, social, financial and economic). On the whole, policies that promote institutional capacity and not personalities which appears to be pervasive in Nigeria, should be pursued, which enable the right person to be in the right place, the right policy to be enacted and pursued at the right time and the right signal sent at the appropriate time, all of which are capable of engendering discipline in the economic system, and thus facilitate higher levels of macroeconomic performance.

\section{References}

Acemoglu, D., Simon, J., \& Robinson, J.A. (2001). The Colonial Origins of Comparative Development: An Empirical Investigation. The American Economic Review, 91(5), 1369-1401. http://dx.doi.org/10.1257/aer.91.5.1369

Anderson, J., \& Marcouiller, D. (2002). Insecurity and the Pattern of Trade: An Empirical Investigation. The Review of Economics and Statistics, 84, 342-352. http://dx.doi.org/10.1162/003465302317411587

Basu, S.R. (2008). A New Way to Link Development to Institutions, Policies and Geography. Policy Issues in International Trade and Commodities. United Nations publication.UNCTAD/ITCD/TAB/38.New York and Geneva.

Bekaert, G., Harvey, C.R., \& Lundblad, C. (2005). Does financial liberalization spur growth? Journal of Financial Economics, 5 37, http://dx.doi.org/10.1016/j.jfineco.2004.05.007

Bencivenga, V.R., \& Smith, B.D. (1991). Financial Intermediation and Endogenous Growth. Review of Economic Studies, 58(2), 195-209. http://dx.doi.org/10.2307/2297964

Benyishay, A., \& Betancourt, R. (2010). Civil liberties and economic Development. Journal of Institutional Economics, 6(3), 281-304. http://dx.doi.org/10.1017/S1744137410000081 
Central Bank of Nigeria (2011), Statistical Bulletin. Abuja, Nigeria.

Chong, A., \& Zanforlin, L. (2000). Law Tradition and Institutional Quality: Some empirical Evidence. Journal of International Development, 12(8), 1057-1068. http://dx.doi.org/10.1002/jid.681

Chousa, J. P., Khan, Haider, A., Melikyan, D., \& Tamazian, A. (2005). Assessing institutional efficiency, growth and integration. Emerging Markets Review, 6, 69-84. http://dx.doi.org/10.1016/j.ememar.2004.09.004

Clague C, Keefer P, Knack, S., \& Olson, M. (1996). Property and contract rights in autocracies and democracies. $J$ Econ Growth, 1(2), 243-276. http://dx.doi.org/10.1007/BF00138864

Clague C, Keefer P, Knack, S., \& Olson, M. (1999). Contract-intensive money: Contract Enforcement, Property Rights and Economic Performance. J Econ Growth, 4(2), 185-211. http://dx.doi.org/10.1023/A:1009854405184

DeGregorio, J., \& Guidotti, P.E. (1995). Financial Development and Economic Growth. World Development, 23(3), 433-448. http://dx.doi.org/10.1016/0305-750X(94)00132-I

Dollar, D., \& Kraay, A. (2003). Institutions, trade and growth: revisiting the evidence. Policy Research Working Paper no. 3004.World Bank.

Easterly, W., \& Levine, R. (2003). Tropics, Germs, and Crops: How Endowments Influence Economic Development. Journal of Monetary Economics, 50(1), 3-39. http://dx.doi.org/10.1016/S0304-3932 (02)00200-3

Edwards, S. (1998). Openness, productivity and growth: what do we really know? Economic Journal, 108, 383-398. http://dx.doi.org/10.1111/1468-0297.00293

Fao, R. (2008). Social institutions and human development. Social Development Working Papers, Paper no. 006 July.

Gallup, J., Sachs, J., \& Mellinger, A. (1998). Geography and Economic Development."Working Paper No. 1856. Harvard Institute of Economic Research.

Greenwood, J., \& Jovanovich, B. (1990). Financial Development, Growth and the Distribution of Income. Journal of Political economy, 98(5), 1076-1107. http://dx.doi.org/10.1086/261720

Huther, J., \& Shah, A. (2005). A simple measure of good governance. In Shah, A. (ed), Public Services Delivery. Washington, DC: The World Bank.

Islam, R., \& Montenegro, C.E. (2002). What determines the quality of institutions?" Background Paper for the World Development Report: Building Institutions for Markets.

Kalonda-Kanyama, I., \& Kodila-Tedika, O. (2012). Institutional quality: Does intelligence matter? University of Kansas Working Papers Series in Theoretical and Applied 
Economics.

Kasper, W., \& Streit, M.E. (1998). Institutional Economics: Social Order and Public Policy. Cheltenham: Edward Elgar.

Kaufmann, D., Kraay, A., \& Mastruzzi, M. (2004). Governance matters III: Governance indicators for 1996-2002. World Bank Policy Research Working Paper no. 3106.

Knowles, S., \& Weatherston, C. (2007). Informal Institutions and Cross-Country Income Differences. CREDIT Discussion Paper no. 06/06.

Kornai, J. (2000). The Road to Free Economy: After Ten Years. Voprosi, Economiki, 12, $42-46$.

La Porta, R. Lopez-De-Silanes, F. Shleifer, A., \& Vishny, R.W. (1999). The Quality of Government. Journal of Law, Economics and Organization, 15, 222-279. http://dx.doi.org/10.1093/jleo/15.1.222

Levchenko, A. (2004). Institutional Quality and International Trade. IMF Working Paper 04/231.

Levine, R. (1998). Financial Development and Economic Growth: Views and Agenda. World Bank Working Paper 1678.

North, D.C. (1990). Institutions, Institutional Change and Economic Performance. New York: Cambridge University Press.http://dx.doi.org/10.1017/CBO9780511808678

Ostrom, E. (2005). Understanding Institutional Diversity. Princeton, NJ: Princeton University Press.

Patterson, K. (2000). An Introduction to Applied Econometrics A Time Series Approach. Macmillan, London.

Ranjan, P., \& Lee, J.Y. (2003). Contract Enforcement and the Volume of International Trade in Different Types of Goods. Mimeo, UC Irvine.

Rodrik, D., Subramanian, A., \& Trebbi, F. (2002). Institutions Rule: The Primacy of Institutions over Geography and Integration in Economic Development," NBER Working Paper No. 9305 (Cambridge, Massachusetts: National Bureau of Economic Research).

Rothstein, B., \& Teorell, J. (2008). What is quality of government? A theory of impartial government institutions. $\quad$ Governance, $21(2), \quad 165-190$. http://dx.doi.org/10.1111/j.1468-0491.2008.00391.x

Scully, G.W. (1992). Constitutional Environments and Economic Growth. Princeton: Princeton University Press.

Voleslang, T., \& Perron, P. (1998). Additional test for a unit root allowing for a break in the trend function at unknown time. International Economic Review, 39, 1073-1100. http://dx.doi.org/10.2307/2527353 
Williamson, O.E. (1995). Transaction-cost economics: the governance of contractual relations. In: Transaction Cost Economics, Vol. 1 (Elgar Reference Collection).

\section{APPENDIX}

Table 1A: Vector Autoregression Estimates

\begin{tabular}{|c|c|c|c|c|}
\hline & RGDP & GE & M1 & $\mathrm{IC}$ \\
\hline $\operatorname{RGDP}_{(\mathrm{t}-1)}$ & $\begin{array}{c}0.587306^{*} \\
(0.10315) \\
{[5.69378]}\end{array}$ & $\begin{array}{r}-24.04612 \\
(18.9883) \\
{[-1.26637]}\end{array}$ & $\begin{array}{r}-0.039765 \\
(0.06202) \\
{[-0.64114]}\end{array}$ & $\begin{array}{r}-0.034698 \\
(0.02369) \\
{[-1.46448]}\end{array}$ \\
\hline $\mathrm{GE}_{(\mathrm{t}-1)}$ & $\begin{array}{r}-0.001205^{*} \\
(0.00036) \\
{[-3.35421]}\end{array}$ & $\begin{array}{c}0.927951^{*} \\
(0.06611) \\
{[14.0369]}\end{array}$ & $\begin{array}{c}-0.000197 \\
(0.00022) \\
{[-0.91018]}\end{array}$ & $\begin{array}{r}-6.54 \mathrm{E}-05 \\
(8.2 \mathrm{E}-05) \\
{[-0.79271]}\end{array}$ \\
\hline $\mathrm{M} 1_{(\mathrm{t}-1)}$ & $\begin{array}{c}0.333793^{*} \\
(0.09845) \\
{[3.39052]}\end{array}$ & $\begin{array}{c}34.36143^{* *} \\
(18.1231) \\
{[1.89600]}\end{array}$ & $\begin{array}{c}1.050780^{*} \\
(0.05920) \\
{[17.7506]}\end{array}$ & $\begin{array}{c}0.031984 \\
(0.02261) \\
{[1.41436]}\end{array}$ \\
\hline $\mathrm{IC}_{(\mathrm{t}-1)}$ & $\begin{array}{c}1.088760^{*} \\
(0.30312) \\
{[3.59189]}\end{array}$ & $\begin{array}{r}-5.585286^{*} \\
(55.7997) \\
{[-0.10010]}\end{array}$ & $\begin{array}{r}0.130632 \\
(0.18226) \\
{[0.71672]}\end{array}$ & $\begin{array}{c}0.980226^{*} \\
(0.06963) \\
{[14.0784]}\end{array}$ \\
\hline $\mathrm{C}$ & $\begin{array}{r}0.068737 \\
(0.14069) \\
{[0.48857]} \\
\end{array}$ & $\begin{array}{r}-0.877782 \\
(25.8993) \\
{[-0.03389]} \\
\end{array}$ & $\begin{array}{r}0.007543 \\
(0.08460) \\
{[0.08917]} \\
\end{array}$ & $\begin{array}{c}0.062150^{* *} \\
(0.03232) \\
{[1.92314]}\end{array}$ \\
\hline $\begin{array}{l}\mathrm{R}^{2} \\
\text { Adj. } \mathrm{R}^{2}\end{array}$ & $\begin{array}{l}0.983 \\
0.982\end{array}$ & $\begin{array}{l}0.991 \\
0.990\end{array}$ & $\begin{array}{l}0.997 \\
0.997\end{array}$ & $\begin{array}{l}0.945 \\
0.940\end{array}$ \\
\hline
\end{tabular}

Note: ${ }^{*}$ and ${ }^{* *}$ indicate statistically significant at $1 \%$ and $5 \%$ levels respectively.

Source: Authors' computations. 
Table 1B: Vector Error Correction Estimates

Panel A: VEC Estimates

\begin{tabular}{|c|c|c|c|c|}
\hline & $\Delta \mathrm{RGDP}$ & $\Delta \mathrm{GE}$ & $\Delta \mathrm{M} 1$ & $\Delta \mathrm{IC}$ \\
\hline CointEq1 & $\begin{array}{c}-0.000778^{* * *} \\
(0.00053) \\
{[-1.48130]}\end{array}$ & $\begin{array}{c}0.496106^{*} \\
(0.06881) \\
{[7.20963]}\end{array}$ & $\begin{array}{r}-7.91 \mathrm{E}-05 \\
(0.00026) \\
{[-0.30082]}\end{array}$ & $\begin{array}{c}0.000191^{* * *} \\
(0.00010) \\
{[1.84395]}\end{array}$ \\
\hline$\Delta \operatorname{RGDP}_{(\mathrm{t}-1)}$ & $\begin{array}{r}0.005534 \\
(0.14733) \\
{[0.03756]}\end{array}$ & $\begin{array}{r}-3.776704 \\
(19.3028) \\
{[-0.19566]}\end{array}$ & $\begin{array}{c}0.047901 \\
(0.07374) \\
{[0.64960]}\end{array}$ & $\begin{array}{r}-0.008731 \\
(0.02910) \\
{[-0.30004]}\end{array}$ \\
\hline$\Delta \mathrm{GE}_{(\mathrm{t}-1)}$ & $\begin{array}{r}0.000498 \\
(0.00100) \\
{[0.49926]}\end{array}$ & $\begin{array}{c}-0.683355^{*} \\
(0.13057) \\
{[-5.23359]}\end{array}$ & $\begin{array}{r}0.000473 \\
(0.00050) \\
{[0.94790]}\end{array}$ & $\begin{array}{r}-0.000477^{* *} \\
(0.00020) \\
{[-2.42318]}\end{array}$ \\
\hline$\Delta \mathrm{M}_{(\mathrm{t}-1)}$ & $\begin{array}{c}0.561228^{* * *} \\
(0.30609) \\
{[1.83354]}\end{array}$ & $\begin{array}{r}29.34301 \\
(40.1036) \\
{[0.73168]}\end{array}$ & $\begin{array}{c}0.326009^{* *} \\
(0.15320) \\
{[2.12797]}\end{array}$ & $\begin{array}{c}0.069704 \\
(0.06046) \\
{[1.15292]}\end{array}$ \\
\hline$\Delta \mathrm{IC}_{(\mathrm{t}-1)}$ & $\begin{array}{r}0.352712 \\
(0.77667) \\
{[0.45414]}\end{array}$ & $\begin{array}{c}86.98259 \\
(101.758) \\
{[0.85480]}\end{array}$ & $\begin{array}{r}0.008944 \\
(0.38873) \\
{[0.02301]}\end{array}$ & $\begin{array}{c}0.180195 \\
(0.15341) \\
{[1.17462]}\end{array}$ \\
\hline $\mathrm{C}$ & $\begin{array}{r}-0.009807 \\
(0.03677) \\
{[-0.26668]}\end{array}$ & $\begin{array}{c}22.55965^{*} \\
(4.81795) \\
{[4.68242]}\end{array}$ & $\begin{array}{c}0.051807^{*} \\
(0.01841) \\
{[2.81478]}\end{array}$ & $\begin{array}{r}0.008033 \\
(0.00726) \\
{[1.10601]}\end{array}$ \\
\hline
\end{tabular}

Standard errors in ( ) \& t-statistics in [ ]. ${ }^{* * *}$ and ${ }^{* * *}$ indicate statistically significant at $1 \%, 5 \%$ and $10 \%$ level respectively.

Panel B: Model Stability Condition

Endogenous variables: RGDP GE M1 IC

Lag specification: 11

\begin{tabular}{ll}
\hline \multicolumn{1}{c}{ Root } & Modulus \\
\hline $0.992757-0.024188 \mathrm{i}$ & 0.993051 \\
$0.992757+0.024188 \mathrm{i}$ & 0.993051 \\
0.911672 & 0.911672 \\
0.649078 & 0.649078 \\
\hline
\end{tabular}

Note: No root lies outside the unit circle.

VAR satisfies the stability condition.

Source: Authors' computations. 
Table 1C: (Alternative Model)

Panel A: Vector Autoregression Estimates

\begin{tabular}{|c|c|c|}
\hline & RGDP & DEM \\
\hline $\mathrm{RGDP}_{\mathrm{t}-1}$ & $\begin{array}{l}0.972345^{*} \\
(44.3421)\end{array}$ & $\begin{array}{r}0.046687 \\
(1.03592)\end{array}$ \\
\hline $\operatorname{DEM}_{t-1}$ & $\begin{array}{r}0.028330 \\
(0.72495)\end{array}$ & $\begin{array}{r}0.821893 \\
(10.2332)\end{array}$ \\
\hline $\mathrm{C}$ & $\begin{array}{c}0.172485^{* * *} \\
(1.62081)\end{array}$ & $\begin{array}{l}-0.151281 \\
(-0.69168)\end{array}$ \\
\hline $\mathrm{R}^{2}$ & 0.98 & 0.71 \\
\hline Adj. $R^{2}$ & 0.97 & 0.69 \\
\hline
\end{tabular}

Panel B: Vector Error Correction Estimates

\begin{tabular}{ccc}
\hline CointegratingEq & \\
\cline { 1 - 2 } RGDP $_{\mathrm{t}-1}$ & 1.000000 & \\
& & \\
DEM $_{\mathrm{t}-1}$ & $-2.609321^{* *}$ & \\
& {$[-2.52493]$} & \\
$\mathrm{C}$ & -3.807100 & $\Delta \mathrm{DEM}^{* *}$ \\
\hline Error Correction: & $\Delta$ RGDP & $0.071296^{*}$ \\
\hline Coint. Eq, & -0.017151 & $(2.39574)$
\end{tabular}

$\begin{array}{lrr}\Delta \mathrm{RGDP}_{\mathrm{t}-1} & 0.045629 & 0.024846 \\ & (0.31077) & (0.08277)\end{array}$

$\begin{array}{ccc}\Delta \mathrm{DEM}_{\mathrm{t}-1} & 0.015004 & 0.070931 \\ & (0.21381) & (0.49442) \\ \mathrm{C} & 0.048836^{* *} & -0.001264 \\ & (2.32672) & (-0.02945)\end{array}$

DEM represents democracy (1 if present and 0 if absent). ${ }^{* * *}$ and ${ }^{* * *}$ indicate statistically significant at $1 \%, 5 \%$ and $10 \%$ level respectively. T-statistics are in bracket.

Source: Authors' computations.

\section{Copyright Disclaimer}

Copyright reserved by the author(s).

This article is an open-access article distributed under the terms and conditions of the CreativeCommons Attribution license (http://creativecommons.org/licenses/by/3.0/). 